\title{
Change in snow cover area of Brahmaputra river basin and its sensitivity to temperature
}

\author{
Swapnali Barman * and R. K. Bhattacharjya
}

\begin{abstract}
Background: The discharge of the River Brahmaputra is highly affected by the melting of snow at the upper part of its catchment. Increase in discharge due to significant retreat of snow in turn affects the downstream flow characteristics of the river giving rise to severe catastrophic problems such as flood and erosion. Rising temperature is one of the major reasons of melting of snow at the upper Brahmaputra catchment. Keeping in mind such issue, in this paper, a study has been conducted to see how the snow cover area of the Brahmaputra river basin changes with respect to the change in temperature. MODIS image MOD09A1.5 (MODIS/Terra Surface Reflectance 8-Day L3 Global 500 m SIN Grid) of $500 \mathrm{~m}$ resolution consisting of seven bands has been taken to prepare the normalized difference snow index maps of the study area. The normalized difference snow index map is then used to obtain the areal extent of snow in the Brahmaputra catchment area. The normalized difference snow index maps were prepared starting from 2002 to 2012 for four different months, viz. January, April, July and October. For temperature data, HadCM3 data of spatial resolution $2.5^{\circ} \times 3.75^{\circ}$ (latitude by longitude) has been used.

Results: The evaluation of the results shows that the snow cover area of the basin shows decreasing trends with respect to the increasing trend of temperature except for the month of January. Further, this study also shows that MODIS data can efficiently be used for snow cover area variation study.

Conclusions: Variation of snow cover area is an indication of climate change as the melting of snow clearly reflects the rise in temperature. The attenuation of river flow due to the melting of snow in the river Brahmaputra basin may affect the downstream discharge of the river giving rise to severe flood and erosion problem. It has also been observed that MODIS data can efficiently be used in mapping snow cover of large areas, because of its good spatial as well as high temporal resolution.
\end{abstract}

Keywords: Snow cover area, Remote sensing, GCM, Brahmaputra, NDSI

\section{Background}

The River Brahmaputra, one of the major river systems of the Indian subcontinent, which originates in the Himalayas, is expected to be much vulnerable to climate change because of substantial contribution from snow and glaciers (Singh et al. 1997; Singh and Jain 2002). During winter, a large extent of mountainous area of Himalayan river basins is covered by snow which starts ablating in the spring due to rise in temperature. IPCC (2001a) has

\footnotetext{
*Correspondence: swapnali.barman@gmail.com

Department of Civil Engineering, Indian Institute of Technology Guwahati, Guwahati, Assam 781 039, India
}

indicated that the average global surface air temperature has increased by $0.6 \pm 0.2^{\circ} \mathrm{C}$ since the late 19th century and it is projected to increase by $1.4-5.8^{\circ} \mathrm{C}$ over the period 1990-2100. Lal and Singh (2001) and Lal (2001) have reported that the average annual mean surface temperature over Indian sub-continent is likely to increase by about 2.7 and $3.8{ }^{\circ} \mathrm{C}$ during the decades of 2050 and $2080 \mathrm{~s}$, respectively. Dyurgerov and Meier (2005) and Prasad et al. (2009) mentioned that in recent years, the glaciers and snowfields of the Himalaya-KarakoramHindu Kush (HKH) mountain belts and Tibetan plateau are found to be amongst the fastest receding glacial and

\section{Springer}

(c) 2015 Barman and Bhattacharjya. This article is distributed under the terms of the Creative Commons Attribution 4.0 International License (http://creativecommons.org/licenses/by/4.0/), which permits unrestricted use, distribution, and reproduction in any medium, provided you give appropriate credit to the original author(s) and the source, provide a link to the Creative Commons license, and indicate if changes were made. 
snow covers in the world. Again, Kulkarni et al. (2007) and Raina (2009) said that the simultaneous fragmentation of the glaciers along with glacial retreats has also degraded the total areal coverage of perennial snow and ice in the $\mathrm{HKH}$ region.

Mountain glaciers are used to detect and monitor local climate change in regions not typically monitored by instrumentation, as they are considered to be sensitive indicators of climate (Haeberli et al. 2007). Due to the large extent and difficult accessibility of high mountainous terrain, remote-sensing techniques provide an efficient way to collect data in such regions. Satellites are well suited to the measurement of snow cover because the high albedo of snow presents a good contrast with most other natural surfaces except clouds (Hall et al. 2002).

Identification of snow cover using only the visible reflected light may be difficult because many things appear as white, such as clouds or even rocks. However, comparing the reflectance of other wavelength, such as infrared, it is possible to differentiate snow from clouds. Snow reflectance is high in the visible $(0.5-0.7 \mu \mathrm{m})$ wavelengths and has low reflectance in the shortwave infrared (1-4 $\mu \mathrm{m}$ ) wavelengths (Nolin and Liang 2000) which enables to distinguish snow from clouds and other nonsnow-covered conditions. Use of the ratio of a shortwave IR channel to a visible channel was determined by Kyle et al. (1978) and Bunting and d'Entremont (1982) to be useful for snow cover mapping, and later utilized by Dozier (1989) to map snow in the Sierra Nevada Mountains. This method is known as Normalize Difference Snow Index (NDSI) method and is one of the very potential methods to map snow cover of an area. Moderate-Resolution Imaging Spectroradiometer (MODIS) imageries have successfully been applied in monitoring snow cover from space using the Normalize Difference Snow Index (NDSI). MODIS data, available since 2000, have proven useful for a large variety of land, ocean and atmospheric applications. Relative to similar sensors such as the Advanced Very High Resolution Radiometer (AVHRR), the MODIS sensor offers some significant advantages. For example, the MODIS provides observations at a nominal spatial resolution of $500-\mathrm{m}$ versus the 1.1-km spatial resolution of the AVHRR. MODIS's data are available continuously (spatially and temporally) and has also several spectral band observations that span the visible and short-wave infrared wavelengths, useful for distinguishing the extent of snow cover (Salomonson and Appel 2004). Most of the MODIS accuracy assessment reported the overall accuracy between 85 and $99 \%$ during clear sky conditions (Parajka and Bloschl 2012).

The impact of climate change at regional scale can be studied effectively by the General Circulation Models
(GCM), which describes the atmospheric process by mathematical equations. The spatial resolution of these models varies from $2.5^{\circ} \times 2.5^{\circ}$ up to $8^{\circ} \times 10^{\circ}$ latitude and longitude. There is considerable confidence in global climate model simulations mainly because GCM principles are based on well-established fundamental laws of physics such as conservation of mass, energy and momentum (Pitman and Perkins 2008). In addition, another source of confidence lies in the models' ability to simulate important aspects of the current and past climates as well as their changes (Randall et al. 2007). GCMs simulate temperature better than rainfall and therefore there is more confidence in predictions of temperature than rainfall (Masanganise et al. 2013). McMahon et al. (2004) in their study have found that the monthly pattern of temperature is generally well reproduced by the GCMs compared to the monthly pattern of precipitation. They calculated the Nash-Sutcliffe efficiency (NSE) (Nash and Sutcliffe 1970), to compare GCM climate data and observed data and found that the median NSEs of all monthly temperature patterns are greater than 0.75 , with $41 \%$ greater than 0.90 . They also concluded that along with few other GCMs, HadCM3 is also a better performing GCM.

There has been no long-term comprehensive in situ monitoring of snow/glacial melt contributing to the knowledge of hydrology in the river basins of the Himalayan region. As a result, studies on snow melt/glacial melt that describe a basin's hydrology lack direct evidence and sometimes appear to be inconsistent (Armstrong 2010; Kaser et al. 2010). Most of the upper parts of the Brahmaputra catchment is covered by Himalayan snow and have major effect on the downstream flow characteristics of the river. Apart from temperature, other climatic factors such as heavy precipitation, wind speed etc. also effect on melting of snow. The effect of wind is important for the melting process of snow or chipped ice (Hasebe and Kumekawa 1994). According to the result of the laboratory experiment, performed by Hasebe and Kumekawa (1994), the relation between the ratio volume of snowmelt water to air temperature and wind speed is nearly linear. They also found that peak discharge is sharp as the wind speed increases and lag time from the beginning of snowmelt runoff to peak discharge is faster according to an increase in wind speed. Rainfall on existing snow cover frequently occurs in spring. At the onset of a rain storm, the snow cover often stores a portion of the rain and consequently attenuates runoff formation. However if the rain persists and the snow cover becomes saturated, any additional melt water will increase runoff formation.

Many studies state that the melting of glaciers is a clear indicator of climate change (Xu et al. 2009) and note that glacier change is the most visible and obvious indicator of changing temperatures (Armstrong 2010; Winkler et al. 
2010). The rising temperature in the Himalayas would affect glacier melt (Barnett et al. 2005). In the present study, thus the temperature factor has been taken into consideration to study its impact on the change in snow cover area of the Brahmaputra river basin.

A widely cited estimate shows considerable variation in the contribution of melt-water across the river basins fed by Himalayan glaciers (Eriksson et al. 2009; Xu et al. 2008) although this varies seasonally and spatially. The importance of melt-water contribution also varies by basin by basin. It is extremely important to the Indus basin and it is important for the Brahmaputra basin. But it plays modest roles for the Ganges, Yangtze and Yellow Rivers (Immerzeel et al. 2010). By region, melt-water contributes $30 \%$ to the total water flow in the eastern Himalayas, $50 \%$ in the central and western Himalayas and $80 \%$ in Karakoram (Xu et al. 2009).

\section{Description of study area}

The Brahmaputra river basin that lies between the coordinates $23.9^{\circ} \mathrm{N}$ to $31.5^{\circ} \mathrm{N}$ latitude and $82.1^{\circ} \mathrm{E}$ to $97.7^{\circ} \mathrm{E}$ longitude is considered in this study. To determine the variation in temperature, the upper Brahmaputra basin has been considered which is mainly responsible for the fluctuations in snow cover area. The drainage area of the Brahmaputra river is approximately $580,000 \mathrm{~km}^{2}$. Originating from the great glacier mass of Chema-Yung-Dung in the Kailash range of southern Tibet at an elevation of $5300 \mathrm{~m}$, it traverses through China and India, before flowing through Bangladesh and emptying into the Bay of Bengal through a joint channel with the Ganga. Figure 1 shows the false color composite image of the Brahmaputra river basin prepared from the MODIS image.

\section{Methods}

\section{Data used}

The variation of snow cover area in the Brahmaputra river basin has been studied starting from 2002 to 2012 for four different months viz. January, April, July and October using the MODIS image, MOD09A1.5 (MODIS/ Terra Surface Reflectance 8-Day L3 Global 500 m SIN Grid)of $500 \mathrm{~m}$ resolution consisting of seven bands (band-1 to band-7). The climate change scenario data used in this study are based on simulations carried out using General Circulation Models (GCMs) for the Fourth Assessment Report (AR4) of the Intergovernmental Panel on Climate Change (IPCC 2007). The gridded temperature data of HadCM3 (Hadley center Coupled Model version 3) model of A2 scenario having spatial resolution of $2.5^{\circ} \times 3.75^{\circ}$ (latitude by longitude) were used to get the average temperature of the upper portion of the Brahmaputra river basin. A2 scenario considers the forcing effect of greenhouse gases and Sulphate aerosol direct effect,

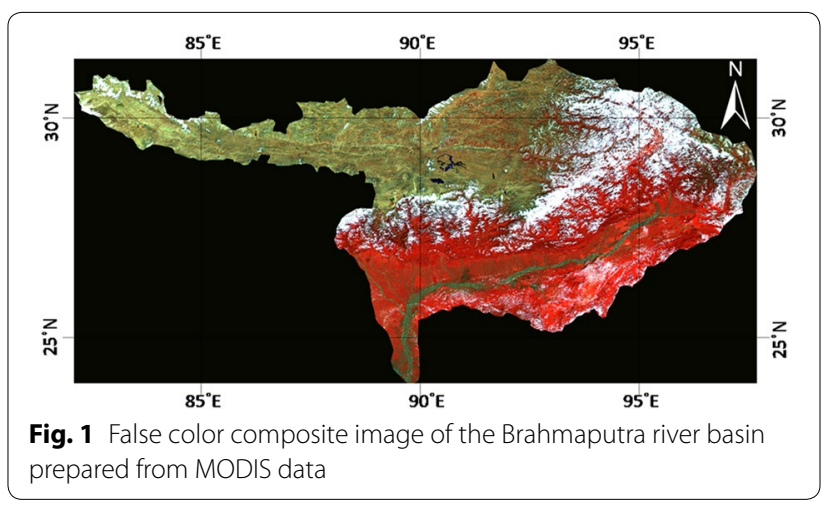

which are based on IPCC SRES-A2 (Special Report of Emission Scenario A2). HadCM3 model was selected since it has the highest 'skill scores' for both precipitation and temperature of all the models used for the AR4 (Cai et al. 2009). This model does not require flux adjustment and has higher resolution compared to other models. The raw data were downloaded from the website of IPCC Data Distribution Centre (http://www.ipcc-data.org/ar4/ gcm_data.html).

The area of Brahmaputra river basin is very large and it is not easy to get the actual temperature data at the upper part of the catchment. Hence, the average temperature values of the GCM points that fall in and around the upper catchment have been used to study the temperature variations at different time period. Miao et al. (2012), assessed the performance of the AR4 GCMs in simulating precipitation and temperature in China from 1960 to 1999 by comparison with observed data, using system bias (B), root-mean-square error (RMSE), Pearson correlation coefficient $(R)$ and Nash-Sutcliffe model efficiency (E) metrics. They observed that GCMs gave reasonably accurate predictions of the temperature, but were less successful at reproducing the precipitation. Again, Mavromatis and Jones (1999) evaluated precipitation and near surface air temperature in two successive versions of the Hadley Centre General Circulation Model (GCM) to consider to what extent GCMs are capable of simulating the mean and variability of local climates. Their conclusion too was positive towards direct use of raw data of HadCM2. Taking the accuracy of GCMs' temperature data as the ground, in this paper, we have used directly the HadCM3 temperature data to study its impact on snowmelt of the Brahmaputra river basin.

\section{Normalized Difference Snow Index (NDSI)}

NDSI method is generally used for snow cover mapping using satellite data (Hall et al. 1995, 2002; Kulkarni et al. 2002, 2006; Negi and Thakur 2008). NDSI uses the high and low reflectance of snow in visible (Green) and 
shortwave infrared (SWIR) region, respectively. Additionally, the reflectance of clouds remains high in SWIR band, thus NDSI allows in discriminating snow and clouds. NDSI ranges from -1 to +1 and is defined by the following relation:

$$
N D S I=\frac{\text { Green }-S W I R}{\text { Green }+S W I R}
$$

where, Green and SWIR are the reflectance of the green and shortwave infrared bands, respectively. Snow has a high reflectance in band-4 $(0.545-0.565 \mu \mathrm{m}$, visible green) and a low reflectance in band-6 (1.628-1.652 $\mu \mathrm{m}$, shortwave near infrared) of the MODIS instrument. A threshold value of NDSI of 0.4 is defined for the pixels that are approximately $50 \%$ or greater covered by snow from imageries of different sensors (Xiao et al. 2001). However, identification of snow covered areas using NDSI is difficult if snow covered areas are mixed with vegetation (Hall et al. 1998). Distinguishing snow from other non-snow features such as water, or dense forests may be difficult because they have similar NDSI readings to snow. To overcome this difficulty i.e., to distinguish these features from snow cover, it becomes necessary to examine other wavelengths. For this, reflectance in band- 2 and band- 4 are examined primarily to separate water bodies and forest, respectively from snow. It is also important to examine the Normalized Difference Vegetation Index (NDVI) to see if a pixel is snow covered forest.

\section{Preparation of snow map}

The Erdas Imagine remote sensing software has been used to prepare the snow map of the study area. The various operations performed were: importing the original, hdf format of the image to img format, mosaicing of all the tiles that cover the Brahmaputra river basin, re-projection of image to geographic latitude longitude and WGS84, sub-setting of the mosaiced image as per the area of interest to get the shape of the Brahmaputra river basin and finally stacking operation was performed to get the image consisting of seven bands.

The high reflective nature of both snow and cloud tops in the visible part of the electromagnetic spectrum, makes cloud indistinguishable from snow. On the other hand, snow is highly absorptive in the short wave infra red part of the electromagnetic spectrum while cloud is highly reflective. NDSI is thus one method that can efficiently differentiate between snow and cloud cover of a satellite image. Pixels that are approximately $50 \%$ or greater covered by snow have NDSI values of 0.4 (Hall et al. 2002). Hence, a threshold value of 0.4 has been taken for snow (i.e. if NDSI $>0.4$, then the pixel is snow, else not snow). In the model maker tool of Erdas imagine, two functions were generated to make the numerator and denominator of the NDSI equation. The data also needs to have 100 added to eliminate negative values and also scaled by a factor of $10^{4}$. For MODIS data, band- 4 represents the green band while band- 6 represents the short wave infrared band. If summation of band- 4 and band- 6 is equal to zero (the denominator), the NDSI was not performed as NDSI value will be infinity. Also, a data value of $-28,672$ was ignored since $-28,672$ is the value of pixels of no data. Again, another function in the model maker was created which considers the pixels having NDSI values of greater than or equal to 0.4 as snow. A total of 44 NDSI images were prepared from 2002 to 2012 for the months of January, April, July and October. Figure 2 gives an overall understanding of the steps to prepare NDSI in the model maker tool of the Erdas Imagine software.

Since water may also have an NDSI of 0.4, an additional test is necessary to separate snow and water. Snow and water may be discriminated because the reflectance of water is less than $11 \%$ in band 2 . Hence, if the pixels with reflectance in band-2 $(0.841-0.876 \mu \mathrm{m})$ was found to be less than $11 \%$ even if the NDSI was greater than or equal to 0.4 , was mapped as water. Similarly, for a pixel where the NDSI was greater than or equal to 0.4 , but the reflectance in band- $4(0.545-0.565 \mu \mathrm{m})$ was less than $10 \%$ was marked as dark forest (Dozier 1989). The reflectance from the forest areas that consists of dense conifers to less dense deciduous forests is considerably darker than non-forested areas even with substantial depths of snow. The challenge is to determine the snow cover areas when they may not be directly detectable. To identify the snow covered forests, the NDVI (Normalized Difference Vegetation Index) was examined. If a pixel NDSI value is less than 0.4 (not snow) but the NDVI is approximately 0.1, the pixel could be snow-covered forest (Hall et al. 2002;

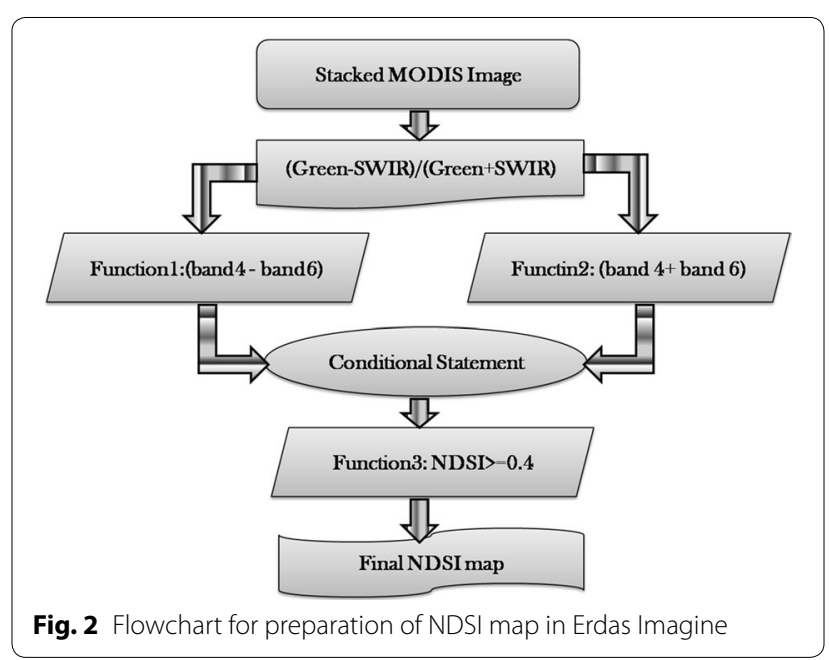


Klein et al. 1998). These measures prevent low reflective features like water bodies and dense forest canopies from being misclassified as snow. Figure 3 shows in detail, the steps to prepare NDVI in Erdas Imagine software. MODIS bands-2 (NIR) and band-1 (Red) are used to create NDVI which can be expressed as,

$$
N D V I=\frac{\text { MODIS band } 2-\text { MODIS band } 1}{\text { MODIS band } 2+\text { MODIS band } 1}
$$

In the NDVI model, the following function was added to create snow forest mask:

$$
N D V I \geq 0.0 \text { and } N D V I<0.2
$$

The created water, forest and NDVI masks were finally applied to the NDSI product to get the final snow map from which the snow cover area can be determined. The values within the NDSI, water, forest and NDVI masks are 1 if true (snow pixel) or 0 if false (non-snow pixel).

\section{Comparison with Landsat data}

Cloud free Landsat satellite data (Landsat 4-5 TM) of $30 \mathrm{~m}$ resolution acquired on April 15, 2010 has been used to validate the snow map prepared from the MODIS image. MODIS image of the same date has been selected for validation. Two small areas of the MODIS snow map have been compared with the high resolution Landsat data. While interpreting visually, it has been observed that the portions covered by snow for both the MODIS and Landsat images (shown in red rectangle in the figure) were same. Apart from visual interpretation, when the area covered by snow for both the MODIS and Landsat images of the selected portions were calculated, the results were almost equivalent. The NDSI map of the Landsat images were prepared by considering band-2

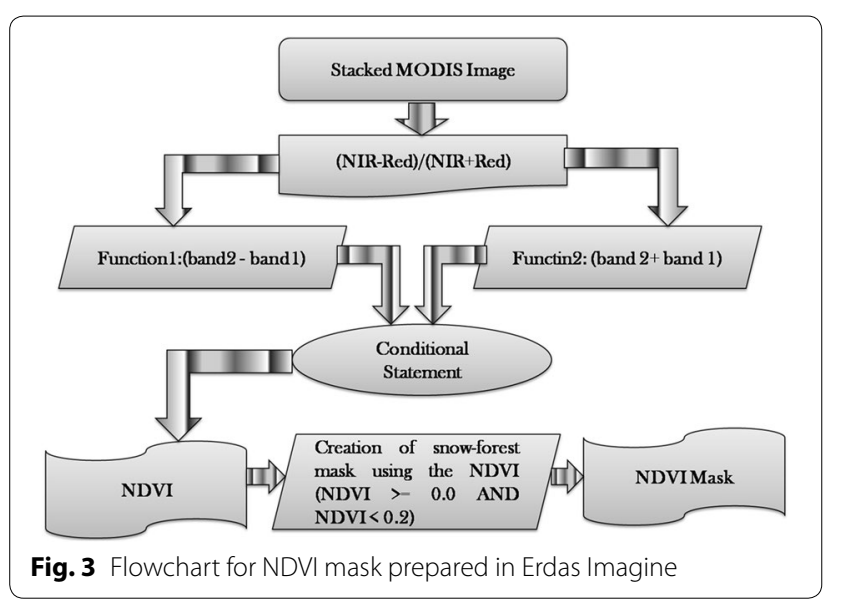

(Green) and band-5 (short-wave infrared). Figure 4a, b show the snow cover map of MODIS image and corresponding Landsat image. For the first portion (Fig. 4a), the area covered by snow in the MODIS image (LHS) was found to be $6012.25 \mathrm{~km}^{2}$, while for the Landsat image (RHS) on the same date, it was $6245.65 \mathrm{~km}^{2}$. Again, for the other segment (Fig. 4b), the snow cover area in the MODIS image (LHS) was found to be $8393.25 \mathrm{~km}^{2}$, while for the Landsat snow map(RHS), it was $8562.25 \mathrm{~km}^{2}$. As the snow cover area for both Landsat and MODIS images were found to be almost equal, the MODIS images were used for studying the snow cover area variation in the present study.

\section{The HadCM3 Model}

HadCM3 (Hadley Centre Coupled Model, version 3) is a coupled atmosphere-ocean general circulation model (AOGCM) developed at the Hadley Centre in the United Kingdom (Gordon et al. 2000; Pope et al. 2000; Collins et al. 2001). HadCM3 does not need flux adjustment to produce a good simulation. In this model, spatial resolution for AGCM3 is roughly $2.5^{\circ}$ of latitude and $3.75^{\circ}$ of longitude forming the global grid of $96 \times 73$ grid cells with 19 levels. In the oceans, this model has a resolution of $1.25^{\circ}$ of latitude and longitude with 20 levels. This model has been used in lot of projects involving climate change and its prediction and has been used in IPCC third assessment report. The HadCM3 GCM points covering the upper Brahmaputra basin have been considered in this study. There were a total of fifteen such points that fall in and around the upper catchment. Figure 5 shows the HadCM3 GCM points considered for temperature evaluation.

\section{Results and discussion}

The snow cover maps for January, April, July and October from 2002 to 2012 have been prepared in the Erdas Imagine software using the methodology discussed above. Figure 6 shows the final snow cover map created using the presented methodology. In the image, the white pixels show the snow cover area while black pixels show the non-snow area. The total area covered by snow for each image as well as the temperature data of HadCM3 for A2 scenario are given in the Table 1 . It can be observed that maximum snow cover area is found either in the month of January or in the month of April. Figure 7 shows the scatter plot for percentage reduction in snow cover area from 2003 to 2012 taking 2002 snow cover area as the base. It may be observed from the figure that percentage reduction in snow cover area increases from 2003 to 2007 compared to 2002 and decreases suddenly in 2008. It again started increasing from 2009 to 2011 and 


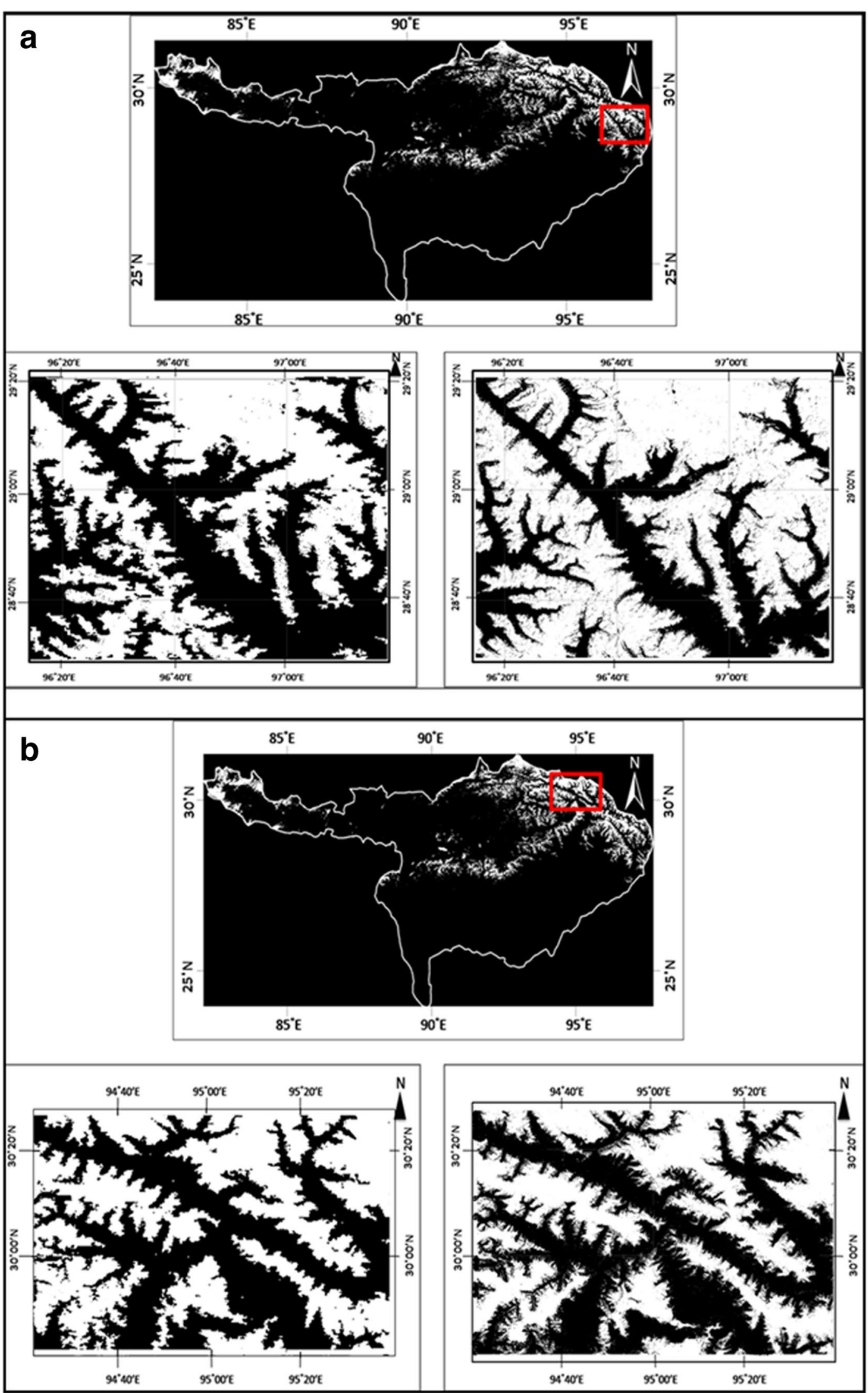

Fig. 4 Comparison of snow cover area of MODIS(LHS) and Landsat (RHS) data for $\mathbf{a}$ the first portion and $\mathbf{b}$ the second portion 

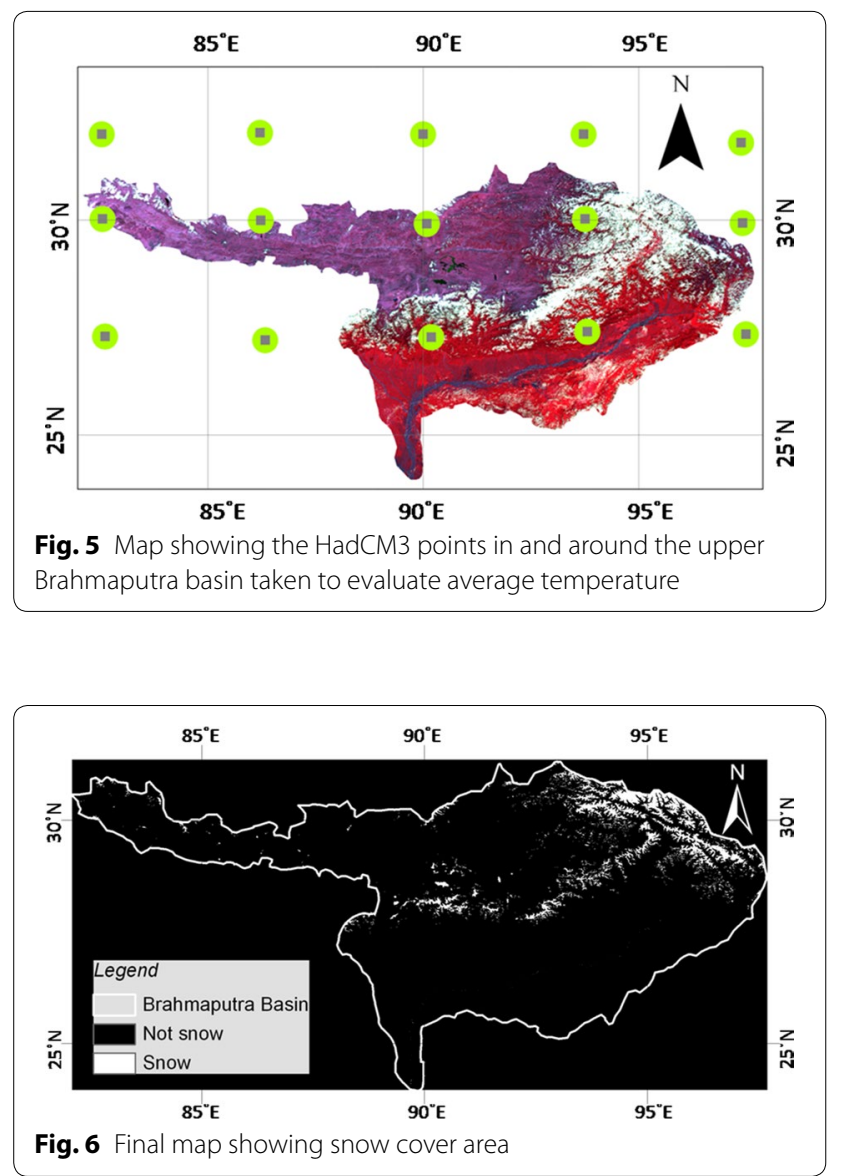

decreases in 2012. The increase in percentage reduction in snow cover area implies that the river is carrying a significant amount of melting water and is affecting the downstream hydrology of the river Brahmaputra. The maximum snow cover area has been observed in 2012 for the month of January with a value of $138,555 \mathrm{~km}^{2}$ and the minimum has been observed in 2007 for the month of July with a value of $7881 \mathrm{~km}^{2}$. The maximum temperature for the entire period from 2002 to 2012 has been observed in 2006 for the month of July $\left(8.85{ }^{\circ} \mathrm{C}\right)$ and the minimum has been observed in 2009 for the month of January $\left(-15.55^{\circ} \mathrm{C}\right)$. The increasing and decreasing trend of snow cover area with respect to the change in temperature for all the four months from 2002 to 2012 are shown in Fig. 8a-d. The results clearly display that the values of temperature taken from the GCM (HadCM3 A2 scenario) for the aforesaid months are increasing gradually from 2002 to 2012 which can be attributed to the fact of global warming. While building a relationship between the snow cover area and temperature data, it has been observed that for the month of January, the snow cover area shows an increasing trend with respect to the increasing trend of temperature. This can be attributed to the fact that a little increase in temperature at subfreezing point may hardly effect the melting of snow. The minimum snow cover during this period was in the year 2008 with a value of $29,822 \mathrm{~km}^{2}$ and the maximum was in the year 2012 with a value of $138,555 \mathrm{~km}^{2}$. While the minimum temperature was in the year $2009\left(-15.55^{\circ} \mathrm{C}\right)$ and maximum was in the year $2008\left(-10.20^{\circ} \mathrm{C}\right)$. For the entire study period from 2002 to 2012, the effect of temperature on snow melt was found to be the maximum in 2008.

For the other three months i.e. April, July and October, the results plotted in graphs (Fig. $8 \mathrm{~b}-\mathrm{d}$ ) show a positive correlation between increase in temperature and decrease in snow cover. Maximum changes have been observed in the month of October. For the month

Table 1 Snow cover area and temperature for different months

\begin{tabular}{|c|c|c|c|c|c|c|c|c|}
\hline \multirow[t]{2}{*}{ Year } & \multicolumn{2}{|l|}{ January } & \multicolumn{2}{|l|}{ April } & \multicolumn{2}{|l|}{ July } & \multicolumn{2}{|l|}{ October } \\
\hline & $\begin{array}{l}\text { Snow cover } \\
\text { area }\left(\mathrm{km}^{2}\right)\end{array}$ & $\begin{array}{l}\text { Temperature } \\
\left({ }^{\circ} \mathrm{C}\right)\end{array}$ & $\begin{array}{l}\text { Snow cover } \\
\text { area (sq. km) }\end{array}$ & $\begin{array}{l}\text { Temperature } \\
\left({ }^{\circ} \mathrm{C}\right)\end{array}$ & $\begin{array}{l}\text { Snow cover } \\
\text { area (sq. km) }\end{array}$ & $\begin{array}{l}\text { Temperature } \\
\left({ }^{\circ} \mathrm{C}\right)\end{array}$ & $\begin{array}{l}\text { Snow cover } \\
\text { area }(\mathbf{s q} . \mathbf{k m})\end{array}$ & $\begin{array}{l}\text { Temperature } \\
\left({ }^{\circ} \mathrm{C}\right)\end{array}$ \\
\hline 2002 & 30,474 & -14.92 & 114,588 & -2.70 & 14,536 & 7.91 & 84,551 & -0.67 \\
\hline 2003 & 98,414 & -12.26 & 99,972 & -1.62 & 25,851 & 8.79 & 21,069 & -1.05 \\
\hline 2004 & 64,472 & -14.22 & 56,236 & -1.09 & 23,695 & 7.20 & 63,894 & 0.93 \\
\hline 2005 & 74,004 & -11.66 & 83,658 & -0.92 & 11,262 & 7.63 & 28,355 & -0.28 \\
\hline 2006 & 37,285 & -13.87 & 80,162 & -3.81 & 12,678 & 8.85 & 16,157 & -2.28 \\
\hline 2007 & 49,892 & -14.43 & 87,833 & 0.81 & 7881 & 8.16 & 12,347 & 1.12 \\
\hline 2008 & 29,822 & -10.20 & 92,263 & 0.16 & 15,540 & 7.84 & 32,572 & -2.00 \\
\hline 2009 & 112,736 & -15.55 & 89,539 & -1.74 & 14,328 & 7.75 & 25,427 & 1.38 \\
\hline 2010 & 66,618 & -11.43 & 68,848 & -0.03 & 12,401 & 7.96 & 30,162 & -3.25 \\
\hline 2011 & 62,421 & -12.88 & 74,142 & -1.69 & 13,038 & 7.91 & 13,129 & 1.43 \\
\hline 2012 & 138,555 & -11.65 & 89,930 & -0.82 & 12,236 & 8.24 & 20,526 & 0.25 \\
\hline
\end{tabular}




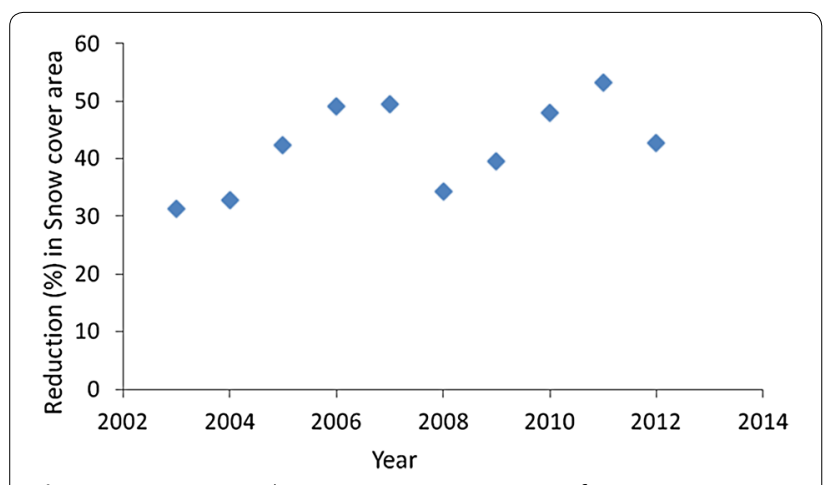

Fig. 7 Percentage reduction in snow cover areas from 2002 to 2012

of April, minimum snow cover was observed in the year $2004\left(56,236 \mathrm{~km}^{2}\right)$ and maximum was observed in the year $2002\left(114,588 \mathrm{~km}^{2}\right)$. For July, the minimum was observed in the year $2007\left(7881 \mathrm{~km}^{2}\right)$ and the maximum was observed in the year $2003\left(25,851 \mathrm{~km}^{2}\right)$. Again, for the month of October, the minimum was observed in the year $2007\left(12,347 \mathrm{~km}^{2}\right)$ and the maximum was observed in the year $2002\left(84,551 \mathrm{~km}^{2}\right)$. In case of temperature, the minimum in the month of April was observed in the year $2006\left(-3.81^{\circ} \mathrm{C}\right)$ and maximum was observed in the year $2007\left(0.81{ }^{\circ} \mathrm{C}\right)$. In case of July, the minimum and maximum temperatures were observed in $2004\left(7.20^{\circ} \mathrm{C}\right)$ and $2006\left(8.85{ }^{\circ} \mathrm{C}\right)$, respectively. On the other hand, for the month of October, the minimum temperature was observed in the year $2002\left(-0.67^{\circ} \mathrm{C}\right)$ and maximum was observed in the year $2011\left(1.43^{\circ} \mathrm{C}\right)$. Apart from the role of temperature, other factors should also be taken into account to explain the reason behind the difference in snow melt trend of the other 2 months from that of January. For example, if the snow is older, its albedo will be
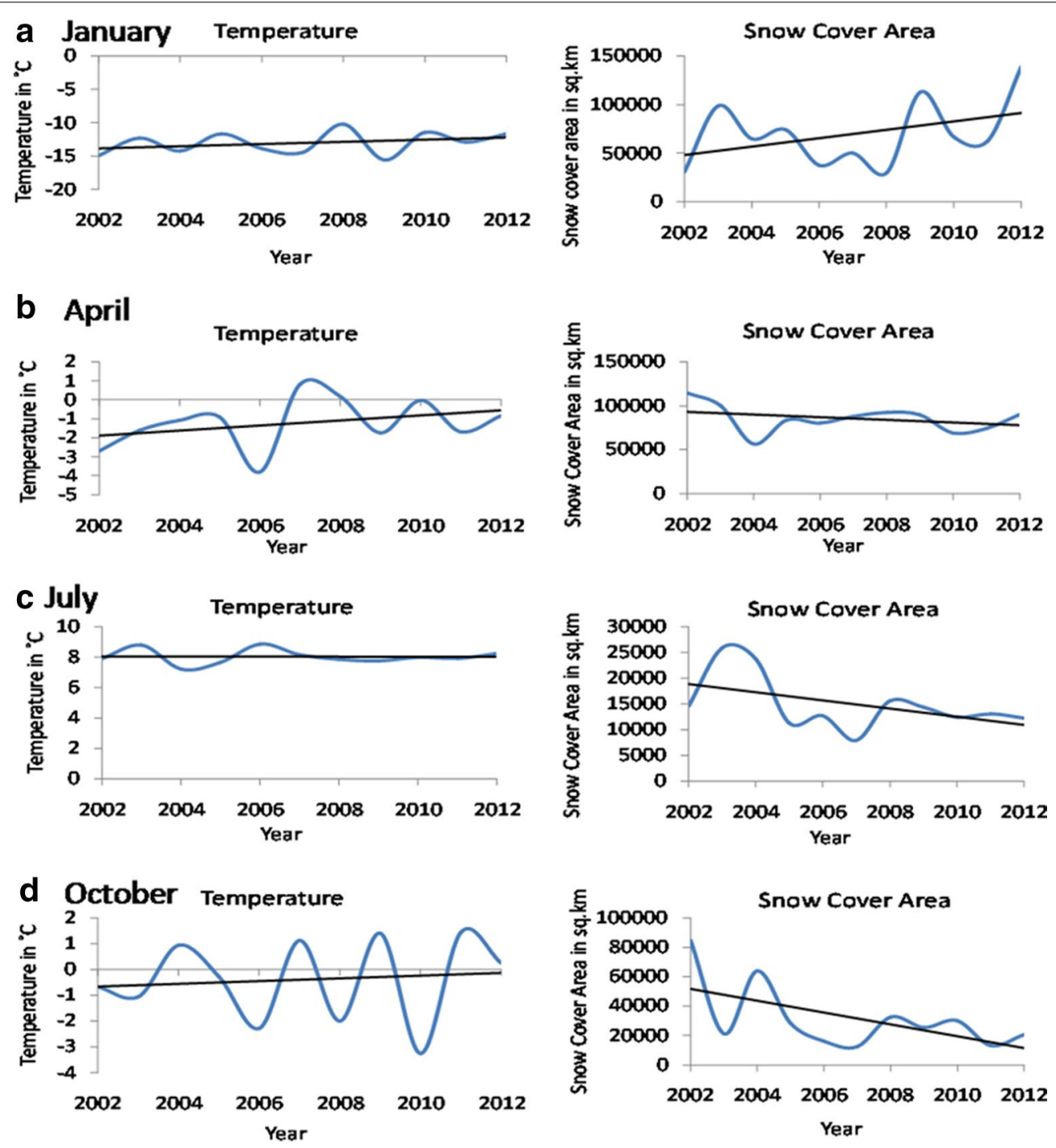

Fig. 8 Trend showing variation of snow cover area w.r.t temperature for the month of a January, b April, c July and $\mathbf{d}$ October from 2002 to 2012 
lower and in such situation it absorbs more solar radiation. Again, if the temperature variation is not significant, snow melts faster in the windy condition than in the calm conditions. However, temperature being a dominant factor, this study evaluated the impact of increase in temperature on the snow cover.

Melting of snow with respect to the rise in temperature has a major impact on the hydrology of the rivers. The flood and river bank erosion caused by the river Brahmaputra at its downstream are the main calamities that affect the livelihood of the people. Though precipitation is considered as the main cause of flood in this region, attention should also be paid to the impact of contribution of snowmelt water to the discharge of the river Brahmaputra. From this study, it has been found that the melting of snow is proportional to rise in temperature. Here a quantitative analysis has been performed to show how much area covered by snow has been reduced due to the rise in temperature from 2002 to 2012 for four different months viz. January, April, July and October. On the basis of these findings, in future, further analysis could be carried out to determine the volume of snowmelt water that contributes to the discharge of the river Brahmaputra. In mountain region particularly, global mean temperature has not been spatially homogeneous. A minor variation in temperature under low magnitude warming is more effective to changes in volume and area of glacier than high magnitude warming. Increase in glacier lakes due to rise in temperature should also be a serious matter of concern. Glacier lakes are formed when the glacier erodes the land, and then melts, filling the hole or space that it has created. A retreating glacier often left behind large deposits of ice in hollows between hills. As the ice age ended, these melted to create lakes (http://en.wikipedia. org/wiki/Glacial_lake).

\section{Conclusion}

In this study, an attempt has been made to correlate change in snow cover area of the Brahmaputra river basin with the change in temperature. It is found that except for the month of January, the snow cover area for other two months i.e. April and October show a decreasing trend with increase in temperature. Thus, significant warming in the snowbound higher Himalayas is causing the growth of existing glacial lakes. The formations of new water bodies have a huge potential of causing damage at the downstream of the river. It has also been found from the study that MODIS data can efficiently be used in mapping snow cover of large areas, because of its good spatial as well as temporal resolution relative to similar sensors such as AVHRR. Since snow reflects more energy in the visible part than in the mid-infrared, the
NDSI ratio enhances the contrast between snow and bare ground. Additionally, the reflectance of clouds remains high in MODIS band-6. Thus, the NDSI can discriminate clouds and snow. MODIS snow map prepared by the method of NDSI was found to be accurate while comparing with the high resolution LANDSAT data of same date. In both the images, the area covered by snow for the selected portions were found to be the same.

\section{Authors' contributions}

SB downloaded all the required data for the study to prepare the snow cover maps and then analyzed the result. She also prepared a draft manuscript for publication. RKB gave the guidance throughout the entire study, reviewed the manuscript and corrected it by giving his own inputs for the betterment of the paper. Both authors read and approved the final manuscript.

\section{Acknowledgements}

The authors are extremely grateful to the editor and the anonymous reviewers of this paper for their constructive and incisive comments and suggestions.

\section{Compliance with ethical guidelines}

\section{Competing interests}

The authors declare that they have no competing interests.

Received: 24 July 2015 Accepted: 28 September 2015

Published online: 09 October 2015

\section{References}

Armstrong RL (2010) The glaciers of the Hindu Kush-Himalayan Region. A summary of the science regarding glacier melt/retreat in the Himalayan, Hindu Kush, Karakoram, Pamir, and Tien Shan mountain ranges. Technical Paper. Kathmandu. ICIMOD and USAID. ISBN 9789291151738

Barnett TP, Adam JC, Lettenmaier DP (2005) Potential impacts of a warming climate on water availability in a snow-dominated region. Nature 438(17):303-309

Bunting JT, d'Entremont RP (1982) Improved cloud detection utilizing defense meteorological satellite program near infrared measurements. Air Force Geophysics Laboratory, Hanscom AFB, MA, AFGL-TR-82-0027, Environmental Research Papers 765, p 91

Cai X, Wang D, Zhu T, Ringler C (2009) Assessing the regional variability of GCM simulations. Geophys Res Lett 36:L02706. doi:10.1029/2008GL036443

Collins M, Tett SFB, Cooper C (2001) The internal climate variability of HadCM3, a version of the Hadley Centre coupled model without flux adjustments. Clim Dyn 17:61-81

Dozier J (1989) Spectral signature of alpine snow cover from the Landsat Thematic Mapper. Remote Sens Environ 28:9-22

Dyurgerov MD, Meier MF (2005) Glaciers and changing Earth system: a 2004 snapshot. Institute of Arctic and Alpine Research, University of Colorado, Boulder, p 117

Eriksson M, Xu J, Shrestha AB, Vaidya RA, Nepal S, Sandstorm K (2009) The changing Himalayas: impact of climate change on water resources and livelihoods in the greater Himalayas. Perspectives on water and climate change adaptation. ICIMOD, Kathmandu

Gordon C, Cooper C, Senior CA, Banks H, Gregory JM, Johns TC, Mitchel JFB, Wood RA (2000) The simulation of SST, sea ice extents and ocean heat transports in a version of the Hadley Centre coupled model without flux adjustments. Clim Dyn 16(2-3):147-168

Haeberli W, Hoelzle M, Paul F, Zemp M (2007) Integrated monitoring of mountain glaciers as key indicators of global climate change: the European Alps. Ann Glaciol 46:150-160

Hall DK, Riggs GA, Salomonson WV (1995) Development of methods for mapping global snow cover using moderate resolution imaging spectroradiometer data. Remote Sens Environ 54:127-140 
Hall DK, Foster JL, Verbyla DL, Klein AG, Benson CS (1998) Assessment of snowcover mapping accuracy in a variety of vegetation-cover densities in central Alaska. Remote Sens Environ 66:129-137

Hall DK, Riggs GA, Salomonson V, DiGirolamo N, Bayr KJ (2002) MODIS snow cover products. Remote Sens Environ 83:181-194

Hasebe M, Kumekawa T (1994) The effect of wind speed on the snowmelt runoff process: laboratory experiment. Snow and ice covers: interactions with the atmosphere and ecosystems (Proceedings of Yokohama Symposia J2 and J5, July 1993). IAHS Publ. no. 423, 1994

Immerzeel WW, Beek LPH, Bierkens MFP (2010) Climate change will affect the Asian water towers. Science 328:1382. doi:10.1126/science.1183188

Kaser G, GroBhauser M, Marzeion B (2010) Contribution potential of glaciers to water availability in different climate regimes. PANS 107(47):20223-20227

Klein AG, Hall DK, Riggs GA (1998) Improving snow-cover mapping in forests through the use of a canopy reflectance model. Hydrol Process 12:1723-1744

Kulkarni AV, Srinivasulu J, Manjul SS, Mathur P (2002) Field based spectral reflectance to develop NDSI method for the snow cover. J Indian Soc Remote Sens 30:73-80

Kulkarni AV, Singh SK, Mathur P, Mishra VD (2006) Algorithm to monitor snow cover using AWiFS data of RESOURCESAT-1 for the Himalayan region. Int J Remote Sens 27:2449-2457

Kulkarni AV, Bahuguna IM, Rathore BP, Singh SK, Randhawa SS, Sood RK, Dhar S (2007) Glacial retreat in Himalaya using Indian remote sensing satellite data. Curr Sci 92:69-74

Kyle HL, Curran RJ, Barnes WL, Escoe D (1978) A cloud physics radiometer. Third conference on atmospheric radiation, Davis, CA, pp 107-109

Lal M (2001) Climatic change-implications for India's water resources. J Indian Water Res Soc 21:101-119

Lal M, Singh SK (2001) Global warming and monsoon climate. Mausam 52:245-262

Masanganise J, Chipindu B, Mhizha T, Mashonjowa E, Basira K (2013) An evaluation of the performances of Global Climate Models (GCMs) for predicting temperature and rainfall in Zimbabwe. Int J Sci Res Publ 3:1-11

Mavromatis T, Jones PD (1999) Evaluation of HadCM2 and direct use of daily GCM data in impact assessment studies. Clim Change 41:583-614

McMahon TA, Peel MC, Karoly DJ (2004) Uncertainty in runoff based on Global Climate Model precipitation and temperature data-part 1: assessment of Global Climate Models. Hydrol Earth Syst Sci Discuss 11:4531-4578

Miao C, Duan Q, Yang L, Borthwick AGL (2012) On the applicability of temperature and precipitation data from CMIP3 for China. PLoS One 7:e44659. doi:10.1371/journal.pone.004465 (pp 1-10)

Nash JE, Sutcliffe JV (1970) River flow forecasting through conceptual models part 1-a discussion of principles. J Hydrol 10:282-290

Negi HS, Thakur NK (2008) Operational snow cover monitoring in NWHimalaya using Terra and Aqua MODIS Imageries. Proc., international workshop on snow, ice, glacier and avalanches, IIT Mumbai, India, 7-9 January, pp 11-25
Nolin A, Liang S (2000) Progress in bidirectional reflectance modeling and applications for surface particulate media: Snow and soils. Remote Sens Rev 14:307-342

Parajka J, Bloschl G (2012) MODIS-based snow cover products, validation, and hydrologic applications. In: Chang Y, Ni-Bin H (eds) Multiscale hydrologic remote sensing perspectives and applications. CRC Press 2012, pp 185-212, Print ISBN 978-1-4398-7745-6, 2012

Pitman AJ, Perkins SE (2008) Regional projections of future seasonal and annual changes in rainfall and temperature over Australia based on skillselected AR4 models. Earth Interact 12:1-50

Pope VD, Gallani ML, Rowntree PR, Stratton RA (2000) The impact of new physical parameterizations in the Hadley Centre climate model- HadCM3. Clim Dyn 16(2-3):123-146

Prasad AK, Yang KHS, El-Askary HM, Kafatos M (2009) Melting of major glaciers in the western Himalayas: evidence of climatic changes from long term MSU derived tropospheric temperature trend (1979-2008). Ann Geophys 27:4505-4519

Raina VK (2009) Himalayan glaciers: a state-of-art review of glacial studies, glacial retreat, and climate change. Ministry of Environment and Forests, Government of India. Discussion Paper, p 56

Randall DA, Wood RA, Bony S, Coleman R, Fichefet T, Fyfe J, Kattsov V, Pitman A, Shukla J, Srinivasan J, Stouffer RJ, Sumi A, Taylor KE (2007) Climate models and their evaluation. Chapter of the book climate change 2007: the physical science basis. In: Solomon S, Qin D, Manning M, Chen Z, Marquis M, Averyt KB, Tignor M, Miller HL (eds) Contribution of working group I to the fourth assessment report of the intergovernmental panel on climate change. Cambridge University Press, Cambridge, pp 589-662

Singh P, Jain SK (2002) Snow and glacier contribution in the satluj river at Bhakra Dam in the Western Himalayan region. Hydrol Sci J 47:93-106

Singh P, Jain SK, Kumar N (1997) Snow and glacier melt runoff contribution in the Chenab river at Akhnoor. Mt Res Dev 17:49-56

Salomonson W, Appel I (2004) Estimating fractional snow cover from MODIS using the normalized difference snow index. Remote Sens Environ 89:351-360

Winkler S, Chinn T, Gartner-Roer I, Nussbaumer SU, Zemp M, Zumbuhl HJ (2010) An introduction to mountain glaciers as climate indicators with spatial and temporal diversity. Erdkunde 64(2):97-118

Xiao X, Shen Z, Qin X (2001) Assessing the potential of VEGETATION sensor data for mapping snow and ice cover: a normalized difference snow and ice index. Int J Remote Sens 22:2479-2487

Xu J, Grumbine RE, Shrestha A, Eriksson M, Yang X, Wang Y, Wilkes A (2008) The melting Himalayas: cascading effects of climate change on water, biodiversity, and livelihoods. Conserv Biol 23(3):520-530

Xu J, Shresth A, Eriksson M (2009) Climate change and its impacts on glaciers and water resource management in the Himalayan Region. Assessment of snow, glacier and water resources in Asia. International Hydrological Programme of UNESCO and Hydrology and Water Resources Programme of WMO

\section{Submit your manuscript to a SpringerOpen ${ }^{\circ}$ journal and benefit from:}

- Convenient online submission

- Rigorous peer review

- Immediate publication on acceptance

- Open access: articles freely available online

- High visibility within the field

- Retaining the copyright to your article

Submit your next manuscript at springeropen.com 